\title{
4
}

\section{Linking management and information systems through case analysis of International Business Operations}

\author{
M. Broadbent \\ Melbourne Business School, University of Melbourne \\ 200 Leicester St, Carlton Vic 3053, Australia
}

\begin{abstract}
The dependence of international business operations on different types of IT provides a valuable teaching and learning opportunity through which to explore the relationships between management and information technology. While some types of IT have now become commodities, business operations in multiple countries often present companies with many choices and challenges. This paper illustrates how the diverse product, market, economic and technological environments of international business operations can highlight the links between business and information strategies in postgraduate management education programs, such as the MBA. We outline three case studies developed specifically to explore these links and explain how management education students can come to understanding that 'all business decisions have IT implications'.
\end{abstract}

\section{Keywords}

IT management, management education, international business

\section{INFORMATION SYSTEMS AND BUSINESS}

Information Systems (IS) ${ }^{2}$ are now an integral part of organisations in business, industry, government and not-for-profit sectors. Most businesses are now heavily dependant on information and technology for competitiveness and survival. The use of information technology (IT) has changed the physical process of producing products and services and

1 Quote from a participant student.

2 We distinguish between IT and IS for the purposes of clarification:

Information Technology includes computer and communications technologies, such as computer hardware (equipment), software (computer programs), telecommunications and communications networks.

Information Systems are the formal organisational systems which rely on IT. They combine the use of information and IT and people for organisational purposes.

IT provides the conduit for messages or content, while IS should result in added value to the 
facilitated the generation of many new products and services. These have had - and will continue to have - an impact on the way organisations are structured and managed. Effective information systems are essential for the day-to-day operation of organisations, for information for decision-making and, in many cases, for the strategic positioning of an organisation's products and services.

The internationalisation of business has considerable implications for information systems. Computer and communications systems are able to manipulate and transmit data at high speeds across long distances. However, a system which is well suited to one environment, might not be satisfactory or adequate in another. Reasons for this might include differences in business practices, markets and consumer expectations, the technology support available in a particular location, the availability of expertise, or government regulations. These factors highlight the inter-relationships between information technology and the organisation, its management and external environments in shaping information systems.

\section{MANAGERS AND INFORMATION SYSTEMS}

Managers in all functional areas now require a working knowledge of IS to ensure that IS investments and business decisions are soundly based. Managers in business units often have responsibility for information systems and for ensuring that the benefits of IS investments are achieved. Critical information systems usually require extensive management input as part of their development and managers can expect to be key members or leaders of teams developing new business systems. In addition, an understanding of the use of information technology can be a key factor in organisational and personal productivity.

With this in mind, participants undertaking professional management programs, such as the MBA, should gain an understanding of the strategic role of information systems in organisations and be able to work as an effective representative of a business or functional area on an information systems development team. They require an understanding of how information systems are used in organisations - or could be used - from a management perspective. Increasingly that management perspective involves responsibilities for business operations in a number of different countries, with different cultures and different types of national and regional IT infrastructures.

We now describe the way in which management education can utilise the strong growth in international business operations to explore the place of IT in the professional education of managers. We examine case studies in three industry areas which have different demands for information and technology support. The three firms have revenues between US\$4bn and US\$12bn and are multi-divisional in structure. Two of the cases involve new business ventures in economic, technological and cultural environments which are very different from their headquarters base. We conclude by identifying the many issues which are examined in these cases and summarise their contribution to establishing the place of IT in management education. 


\section{THREE TEACHING CASES}

The three cases examine:

- the establishment of a new banking business in an emerging economy

- IT support provided for the exploration of an offshore oilfield

- the deployment of IT in a boxmaking business around the world

Extensive onsite visits, involving both business and IT managers, were integral to the development of the cases. The firms and businesses were part of Phase 1 of a research project examining the implications of international business operations for IT management and service delivery. The cases are between 14 and 27 pages long and include extensive firm exhibits. Each case has multiple uses and includes a core set of questions for teaching purposes.

We summarise each of the firms and indicate the focus of each case.

\subsection{Case 1 - Financial Services Industry - Banking: Establishing a New Banking Business: Union Banking Group's Operations in Ragaan (pseudonyms for reasons of commercial sensitivity) (Broadbent, 1995a)}

In the early 1990s, the Ragaanese government granted the first licences to foreign banks to operate in the country. The Overseas Commercial Banking Group (OCBG), based in Australia, was granted a commercial banking licence to operate in the capital of Ragaan, Pesar. The OCBG was the first bank domiciled in an English-speaking country to be granted such a licence.

This case, in three parts, provides an opportunity to examine the different types and levels of IT support required for different stages of a new business. Parts 1 and 2 of the case examine the start-up of OCBG's operation in Pesar, the nature of the banking business, the initial technological support required in a country with limited infrastructure, and ongoing business challenges. Part 3 summarises the factors leading to successful establishment of the business to the end of 1995 and provides a basis to consider growth areas and a changing competitive situation.

The case lends itself to role playing and a consideration of multiple options. What would the students do if they found themselves in the situation of the foundation manager: I arrived with a banking licence in one hand and my suitcase in the other and that was all there was'. The manager did not have a strong IT background and had to start up a banking business in a country with no local IT support. The firm considered the appointment of specialist IT staff too expensive.

\subsection{Case 2 - Resource Industry, Petroleum: IT Supporting New Oil Fields - BHP Petroleum in Vietnam (Broadbent, 1995b)}

BHP is an Australian-based conglomerate with a revenue of over US\$12bn operating a range of international businesses in the mining, energy, heavy manufacturing and IT services industries. In December 1992, BHP Petroleum (BHPP) signed an agreement with the Vietnamese government to lead the development of the Dai Hung (Big Bear) oil and gas field off the coast of Vietnam. BHPP had 18 months to bring the oil on stream if it was 
to retain the right to develop the field further. Early in 1993 the Information Resources group of BHPP's Australia Division was asked to plan the information technology support required for the operation.

This case traces the planning and implementation of the IT support for the Dai Hung project. The establishment of the IT operation faced many challenges as the number of exploration, development and management staff based in Vietnam grew rapidly. These challenges included an embargo on US-made equipment and software, absence of vendor support, limited national telecommunications infrastructure and cost pressures.

BHPP carefully choose three core IT staff to lead the local operation. With the development of Vietnam's technological infrastructure, the business decided to utilise the firm's international communications network to process some data and to lower communications costs. The case includes extracts from BHPP's Guidelines for the Provision of Standard Information, Computing and Communication Services to Site Offices. The provides an avenue for highlighting the role, importance and benefits of standardisation of technology and systems across businesses operating in different parts of the world.

\subsection{Case 3 - Manufacturing Industry - Boxmaking: Amcor Fibre Packaging's Deployment of Information Technology (Broadbent, 1995c)}

Amcor Fibre Packaging (AFP) is one of the world's largest corrugated fibre packaging business, with 70 manufacturing sites and distribution centres in 10 countries. AFP's businesses in different parts of the world deal with different types of customers and markets and different local needs and expectations. AFP's management is decentralised in a firm which values both local independent business operations and a strong an shared sense of corporate commitment.

This case examines the use of IT amongst AFP's businesses. AFP has a variety of information systems operating in its plants around the world. The business has no common infrastructure or communications network and chooses not to share systems or data. The businesses operate independently and so does each information system. There are some opportunities to share expertise. AFP's New Zealand operations has a software company, Kiwiplan, which has developed an integrated suite of packages for managing corrugated boxmaking operations, including sales/order processing and management reporting. However the use of this software is not mandated and those parts of the business which do use it do so following a competitive analysis of business-relevant software.

AFP's approach to the management of information systems is encapsulated in the words of the Managing Director: 'If we did have an IT director across the business, I am not sure what that person would do. We have a strong focus on local accountability and prefer to run the business with a minimum of mandates'. The boxmaking business approach provides a contrasting approach to the banking and petroleum cases causing students to question the contingent nature of information systems in organisations. 


\section{GENERIC ISSUES IN THE CASES}

\section{The Role of Technology and Systems}

Each case identifies specific and critical roles for technology and systems in different firms: even a small financial services operation cannot function adequately without information technology and systems; IT capability underlies the ability to process and manipulate extensive exploration data in the petroleum firm; at a manufacturing site, IT enables the efficient operation of processes and the management of customer information data.

\section{Industry Differences in the use of IT}

The three cases, when used in the same course, are particularly useful for highlighting industry differences in the use of IT: in a financial services firm, customers interact directly with information systems or they are present when used by a firm employee. Information systems are used by operational/service staff and by management. In the petroleum firm however, the most sophisticated systems are used by knowledge workers who are themselves skilled in petrotech systems. There is virtually no interaction with the end consumers of the products generated by the business. In the manufacturing case, the extent of use various amongst AFP's different business units around the world: in some situations, the systems pervade the whole value chain, while in others the systems are largely used by operational staff.

\section{Strategic Drivers and IT}

The link between strategic drivers and the use of IT can be drawn from each case. Contextual information and quotes from management clearly indicate the strategy of each business. By way of example, a generic alignment model (see figure 2) can be applied to the start-up bank (see figure 1), providing a rich source of discussion and later comparison with other businesses.

Case details can be used to assess the extent to which the IT and systems developed met the needs of the strategy drivers as well as other organisational factors, such as decision-making approaches (for example, local autonomy in the case of AFP). The cases provide reinforcement of the strategic importance of sound management of the company's IT investment to achieve their business objectives.

\section{SPECIFIC ISSUES}

While each case was developed with particular teaching purposes in mind and based on a specific issue faced by the firm, we have found that the cases raise multiple issues and can be used as a basis for discussion and learning in many different areas.

Specific examples are:

- Country and cultural differences and how they can impact on the options and solutions for an industry and business (Boxmaking)

- The impact of different value disciplines and competitive approaches within firms which lead to diverse information systems (Boxmaking)

- The way in which the role of IT changes as business develops, eg from support to strategic in the start-up bank 
- The initial timeframes and urgency in banking and petroleum cases which acknowledges the real pressures faced by start-up businesses. This aspect might also be most useful for IT students to help them appreciate that business pressures usually override ideal solutions.

- The respective roles of business and IT management and the importance of the relationships between them (banking)

- The constraints faced by businesses, particularly in newly emerging economies, eg the lack of a skilled IT workforce, minimal vendor support (banking and petroleum)

- How to transfer expertise from one part of the business to another. This is covered in each case, but the businesses take quite different approaches

- The importance of communications management and its changing role in business (banking and petroleum)

- The business significance and functionality of leveraging IT infrastructure from a headquarters or regional base (banking and petroleum)

- The role of IT architecture, standards and the importance of connectivity (petroleum)

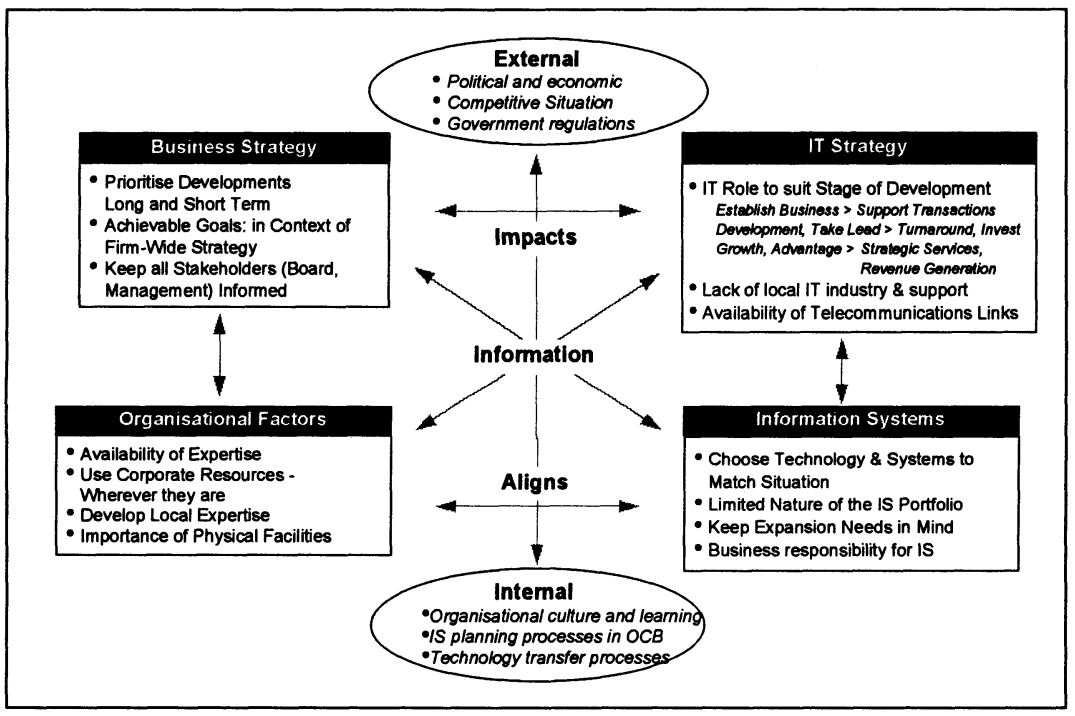

Figure 1 Establishing a New Business - Lessons from Ragaan

\section{EXPERIENCES OF CASE TEACHING}

Placing IT management and business issues in the context of international business can provide a stimulating and thought-provoking classroom experience. The first experience of teaching the start-up banking case was illuminating for both students and instructor. The consistent feedback from students was articulation of the realisation that, in the words of one student: 'All business decisions have IT implications'.

These cases have been taught with postgraduate management classes ranging in size from 40 to 90 . In these groups, all students have at least some professional work 
experience and thus have some appreciation of the complexity of how organisations really function and the importance of their operating environments. In these classes too we have usually had a broad mix of international students who are able to add further dimensions from their own experiences.

The challenges faced by firms operating internationally magnify those operating in more confined geographical and cultural spaces. Management students with aspirations to work internationally are motivated to seriously consider the complex and critical interaction between business and the deployment of information systems and technology.

\section{ACKNOWLEDGMENTS}

Funding for the development of the cases was provided by the Melbourne Business School Foundation which is funded by the Australian business community. Thanks are due to Carey Butler for her work on co-authoring the cases. Special thanks are due to the organisations who provided ready access to their senior business and IT management to develop these and other teaching cases focusing on international business operations. Subsequent research for Phase 2 of the research project examining the impact of international business operations on IT strategy has been supported by Hewlett Packard Australia.

\section{ALIGNING BUSINESS \& INFORMATION SYSTEMS}

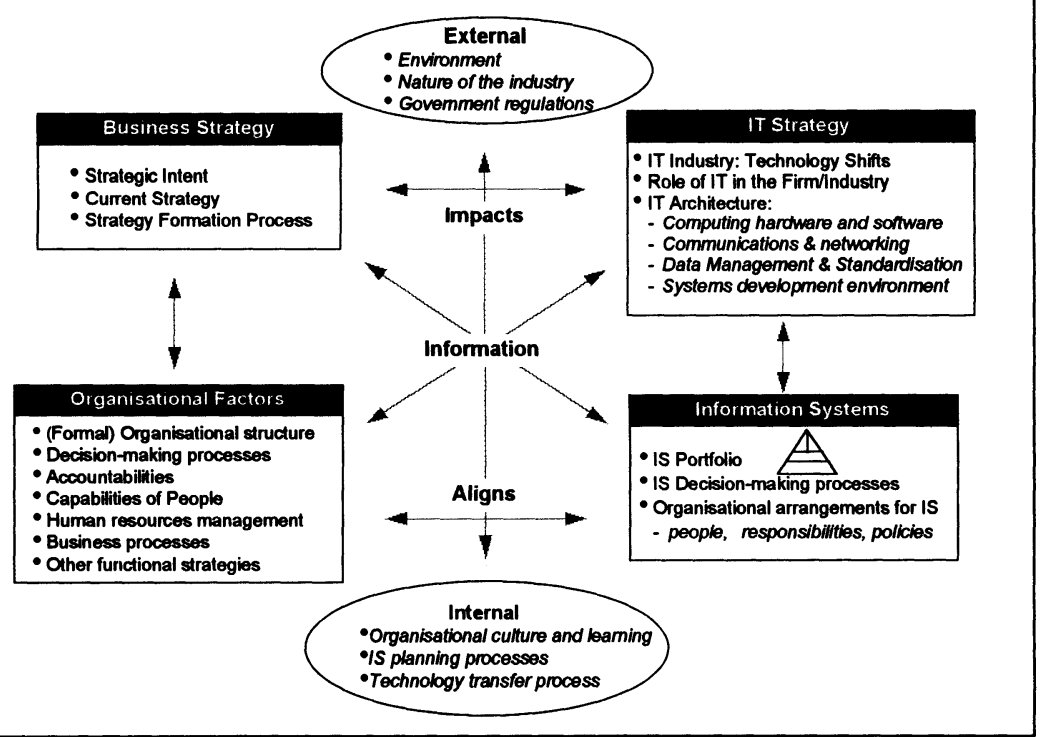

Figure 2 A Generic Alignment Model 


\section{REFERENCES}

Broadbent, M.\& Butler, C. (1995a) Establishing a new banking business: Overseas Commercial Banking Group's Operations in Ragaan. Part 1 The Licence Granted; Part 2 The Start-Up; Part 3 Success Factors to Date. Melbourne Business School, University of Melbourne.

Broadbent, M. \& Butler, C. (1995b) Information Technology supporting new oil fields: BHP Petroleum in Vietnam. CL 330, Melbourne Case Study Services, Melbourne Business School, University of Melbourne.

Broadbent, M. \& Butler, C. (1995c) Amcor Fibre Packaging: Deployment of Information Technology. CL 331, Melbourne Case Study Services, Melbourne Business School, University of Melbourne.

\section{BIOGRAPHY}

Dr Marianne Broadbent is Associate Professor (Management of Information Systems) at the Melbourne Business School, University of Melbourne, where she teaches information systems management and research methods in the MBA, Master of Management (Technology) and in executive programs. Marianne's research and consulting activities focus on the alignment of business and information strategies, managing information technology infrastructure, business process redesign and the implementation of international business operations for information strategies. Prior to joining the School, Marianne was Head of the Department of Information Services at RMIT and had industry and consulting experience in the development, management and evaluation of information services. She is currently Asian and Pacific Editor for the Journal of Strategic Information Systems and Business Change and Reengineering. 